ISSN: 2599-3496 print

ISSN: 2614-2376 online

\title{
Palm Oil in Gelato for Better Melting and Mouthfeel Properties
}

\author{
Eddy Kemenady*, Muhammad Eka Pramudita, Muhammad Arief Prabawa \\ PT Kemenady Industri Mandiri, Bogor 16121, Indonesia.
}

\begin{abstract}
Recently, the growth of gelato outlets in Bali, Surabaya, Jakarta, and many cities in Indonesia hit $30-45 \%$ since 2013 to 2018 . The gelato outlet has good margin at least $50 \%$ gross profit. However, the consumers need gelato not only good in taste but also it is not easy to melt. In modern world the formulations are based on premix of modified starch, sugar, emulsifier, stabilizers and milk solid nonfat. One of most popular brands of gelato premix is imported from Italy. In recent years, the use of palm oil in gelato is hardly reviewed. However, in ice cream business, palm oil is used widely. The fat blends of palm oil and palm kernel oil at PO/PKO (30/70; w w $^{-1}$ ) was used, because the solid fat content (SFC) properties is similar to the SFC of butter oil. The level of this fat blend in gelato was varied from $5,8,10$ and $12 \%$. This research showed that the optimum fat blend addition in formula was found at $8 \%$. The dripped test is used at $28{ }^{\circ} \mathrm{C}$ ambient temperature to measure heat stability. It was found that the more fat blend in gelato, the more stable the texture to heat shock and made the gelato easy to scoop as well. The cost in formulation with this $8 \%$ palm oil blend to gelato formulation is only $2.8 \%$. Therefore, the palm oil blend in gelato formulation gives significant improvement melting and mouthfeel properties at insignificant cost addition.
\end{abstract}

Keywords: butter oil, gelato, palm kernel oil, palm oil, solid fat content

\section{INTRODUCTION}

In last 5 years, the gelato shops in several big cities in Indonesia grew significantly. Referring to italian trade agency (ITA) in January 2018, the growth of importation of gelato machine from Italy to Indonesia was $30-48 \%$ in value or 4.3 million USD. The growth of machine importation related to the opening of gelato shops in Bali, Jakarta, Surabaya and other big cities. The acceptance of gelato products within those cities are very good with several well know brand such as seperti gusto gelato, gelato factory, riva reno gelato in Bali. The well-known gelato shops in Surabaya such as gourmet gelato, frut-o gelato, bebini gelati and many others.

Most of gelato shops use the gelato premix from Italia with several brands. The most famous brand is MEC3 with its panna base which widely used. Some gelato shops make their own artisanal

*Corresponding author:

PT Kemenady Industry Mandiri,

Jalan Pengadilan No. 23 B, Bogor 16121, Indonesia.

Email: eddy@kemenady.net 
recipes using fresh milk and gelatin. However, by formulation calculation most of gelato recipes has low fat level such as $2-4 \%$. The fat comes from the milk solid which is used such as skimmed milk powder, whey powder, butter milk powder, etc. (Robert 2000). The addition of cream milk which contains $25-40 \%$ butter fat is rarely used because of the cost and freshness issue. Most of cream milk for gelato shops uses UHT with limited shelf life.

The common approach to improve the cost and melting behavior is reducing the use of gelato premix. However, this approach makes the gelato too sweet and icy because sugar is added as a cheaper material and makes lower melting point (Robert 2000). The alternative to cream milk such as butter fat and milk fat is also not common in this gelato formulation in Indonesia due to supply limitation and cost issue. The butter fat and butter oil are imported in drums of $200 \mathrm{~kg}$ which is not practical in gelato shops.

The use of palm oil blends is hardly found in gelato formulation due to the originality of gelato recipes are made from fresh milk, cream milk, sugar, gelatin, and fresh fruits. However, the consumers found these formulations are not stable in tropical temperature such as to 28 to $32^{\circ} \mathrm{C}$ in most Indonesian climates. Therefore, most of gelato shops needs tables dan chair to enjoy the gelato in the rooms. In ice cream products, most of products are consumed out of home or impulse due its melting behavior specially to heat shock in tropical climate. In order to get more out of home consumption of gelato in Indonesia, the palm oil as source of fat in ice cream can be explored to improve the melting behavior of gelato. Gelato is also having low overrun at $20-30 \%$ in comparation to ice cream to $80-100 \%$. The lower overrun makes structure of gelato thicker than ice cream. The level of fat in ice cream in Indonesia regulation (BPOM
Kategori Pangan 2016) minimum is $5 \%$. Therefore, the addition of fat in gelato formulation can follow ice cream to have $5 \%$ minimum by palm oil addition. So far no regulation on gelato in Indonesia as food categorization.

The palm oil in ice cream and gelato formulation needs to meet the butter oil melting behavior. The blend of refined palm oil (PO) and refined palm kernel oil (PKO) has interested behavior to butter oil in solid fat content (SFC). Noor Lida Habi Mat Dian . in Journal of America Oil Society in 2002 explored the combination of fat blend of PO and PKO for their SFC at several temperatures. The other finding was in the International Journal Of Engineering and Technical Research (IJTER) (2017), Amita showed the butter oil analyses in comparison to palm oil. The SFC behavior of those fat blend PO and PKO is shown in the following chart (Figure 1).

The SFC of 30PO/70PKO has closely patterns in wide range of temperatures to butter oil. Therefore, the use of this fat blend in the gelato formulation is expected to replace the butter oil which is mainly coming from fresh milk and cream milk. The level of this fat blend is varied from $5,8,10$ and $12 \%$ following the minimum of fat level in SNI 01-3713-1995 on Ice Cream which stated the minimum of fat at $5 \%$.

The assessment of heat stability was done with a dripped test of $65 \mathrm{~g}$ sample at ambient $28{ }^{\circ} \mathrm{C}$ temperature. The sample is located above a weighing scale in a container to measure the speed of melting part from gelato on it. The reference is the panna base premix from MEC3 with recommended recipe with coded $0 \%$ fat. The sample was put in a plastic cup then weighted to get $65 \mathrm{~g}$ of samples. Then the sample was put on the perforated bowl to let the gelato drip on the container with the weighing scale. The assessment was made based on the speed of dripping 


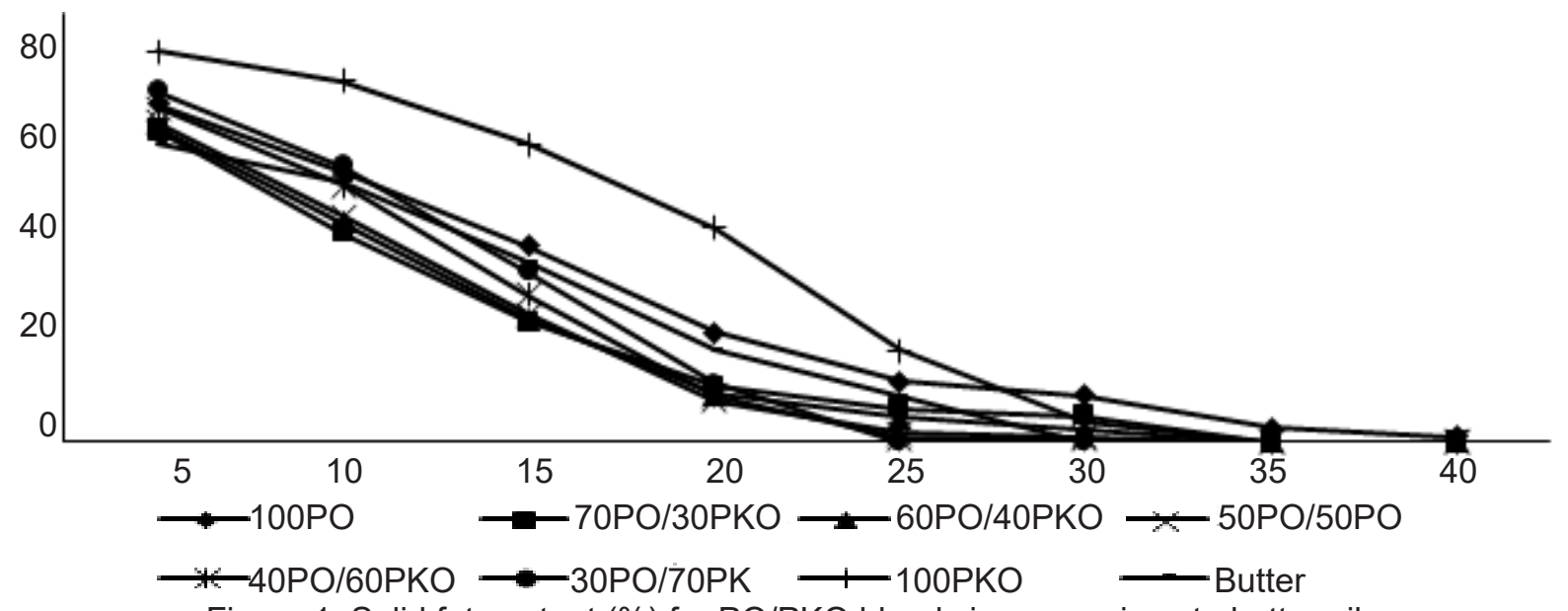

Figure 1 Solid fat content (\%) for PO/PKO blends in comparison to butter oil Source: Noor Lida 2002 and Amita 2017

against the time; the more gelato dripped the more unstable it was.

The organoleptic assessment was done with tasting sessions with the group to make scoring on the mouthfeel and taste preferences. The attributes of fatty after taste with scale of 7 was used. The overall preference was asked to assess the final tasting sessions.

\section{MATERIALS AND METHODS}

\section{Materials}

\section{Gelato Premix MEC3}

The sample of $2.5 \mathrm{~kg}$ MEC3 panna base was used as the gelato premix on this assessment. The sample was purchased from its agent lotus food services in Jakarta. The price was IDR 350000 per $\mathrm{kg}$. The recommended formula was $50 \mathrm{~g}$ of this premix is used in $1000 \mathrm{~mL}$ of fresh milk and $200 \mathrm{~g}$ of sugar. In this test the sugar level was reduce to $100 \mathrm{~g}$ because of recommended formula the taste was too sweet (Table 1).

\section{Palm Oil and Palm Kernel Oil}

The samples of refined palm oil and palm kernel oil were obtained from Asian Agri Jakarta from its normal production. The specifications of these refined oils are as follows Table 2.
Table 1 Nutrition fact of panna base MEC3

\begin{tabular}{lccc}
\hline Nutrition & \multicolumn{2}{c}{$\ln 100 \mathrm{~g}$} & $\% \mathrm{w} \mathrm{w}^{-1}$ \\
\hline Energy & 379 & $\mathrm{kcal}$ & \\
Fat & 5.4 & $\%$ & 5.4 \\
Saturated fats & 5.1 & $\%$ & 5.1 \\
Carbohydrate & 66 & $\mathrm{~g}$ & 0.66 \\
Sugars & 44 & $\mathrm{~g}$ & 0.44 \\
Protein & 14 & $\mathrm{~g}$ & 0.14 \\
Salt & $3.25 \mathrm{~g}$ & 0.03 \\
\hline
\end{tabular}

Table 2 Refined Oil Specification Source: Asian Agri

\begin{tabular}{lccc}
\hline Parameter & UOM & $\begin{array}{c}\text { Refined } \\
\text { Palm } \\
\text { Kernel }\end{array}$ & $\begin{array}{c}\text { Refined } \\
\text { Palm } \\
\text { Oil }\end{array}$ \\
\hline FFA (as palmitic) & $\%$ max & 0.05 & 0.1 \\
M \& I & $\% \max$ & 0.1 & 0.1 \\
I.V & & $14-19$ & $50-55$ \\
M.Pt degrees C (AOCS) & $33-39$ & $26-30$ & $33-39$ \\
$\begin{array}{l}\text { Cc 3-5 } \\
\text { Colour (5.25" lovibond } \\
\text { cell }\end{array}$ & Red & 4 & 6 \\
Peroxide value & max & & \\
\hline
\end{tabular}

The cost of refined palm oil is \pm IDR 10000 per kg and \pm IDR 12000 per kg for refined palm kernel oil.

\section{Cows' Milk}

UHT full cream plain was used for the source of cows' milk in this research. The 
fat content was $3 \%$ and the protein content was 3\%. The price was IDR 16000 per liter.

\section{Cane Sugar}

Cane sugar was used as branded sugar Gulaku with yellow label. The price was IDR 12100 per kg.

\section{Equipment}

\section{Cuisinart ICE-100BCHK}

The desk gelato machine cuisinart was used at $1000 \mathrm{~mL}$ batch size. The machine made the gelato at $-3{ }^{\circ} \mathrm{C}$ from pasteurized and chilled gelato mix.

\section{Chest Freezer}

A chest freezer was used to keep the gelato frozen at -15 to $-17^{\circ} \mathrm{C}$ before serving and tasting.

\section{Dripped Test Apparatus}

This dripped test apparatus was common in ice cream industry. It consisted of digital weighing scale at $1000 \mathrm{~g}$ with timer. Then a stand to hold the perforated bowl was used for putting the gelato $65 \mathrm{~g}$ from plastic cup. The on the weighing scale was put a tray to hold the dripped gelato to be measured and function of time.

\section{Phillip Promix}

This electrical mixer was used to homogenize the gelato premix after being pasteurized on the stove. The lumps dan fat globules were dispersed using this mixer to make a homogenous gelato mix.

\section{LPG stove - Modena}

The stove with LPG flame was used to pasteurize the gelato mix.

\section{Digital Thermometer AZ-668-SHR}

A digital thermometer with $-50{ }^{\circ} \mathrm{C}$ to 140 ${ }^{\circ} \mathrm{C}$ range is used to monitor the heating, cooling, and freezing process.

\section{Kitchen utensils}

Basic kitchen utensils are used such as knife, bowl, pan, wooden stirrer, spoon, plastic cups and paper towels.

\section{Method}

The gelato was made in a normal kitchen with the following steps Figure 2. The gelato was made using kitchen equipment as mentioned above. The batch size was $500 \mathrm{~g}$ for each formula as follows Table 3.

\section{RESULTS AND DISCUSSION}

\section{Melting Behavior}

The melting behavior of these samples can be seen below. The samples must frozen 24 hour at $-15{ }^{\circ} \mathrm{C}$ before being used in the dripped test. The run of dripped test was done duple for each formulation at ambient temperature $27-29^{\circ} \mathrm{C}$ (Avg. $28^{\circ} \mathrm{C}$ ) (Figure 3).

The difference of amount dripped gelato showed more and more after 30 minutes. The observation was stop after 60 minutes. The overall findings showed that the addition of fat blend gave more stable shape and less melted gelato.

\section{Mouthfeel Evaluation}

Sensory evaluation was done by 6 expert panelists who like gelato in their selection of frozen dessert. There are 6 attributes to be explored. The average preference was tabulated in Table 4 . The overall preference went to gelato with $8 \%$ fat blend addition at 6 average point to 7 scale. The cold eating sensation was detected less icy with the more fat blend added. However, the fatty after taste was found high with more fat blend in gelato as can be seen in Table 4 below.

The SFC approach to determined fat blend 30PO/70PKO showed good acceptance from $5 \%$ to $12 \%$ in the basic gelato formulation using Panna Base formulation. 


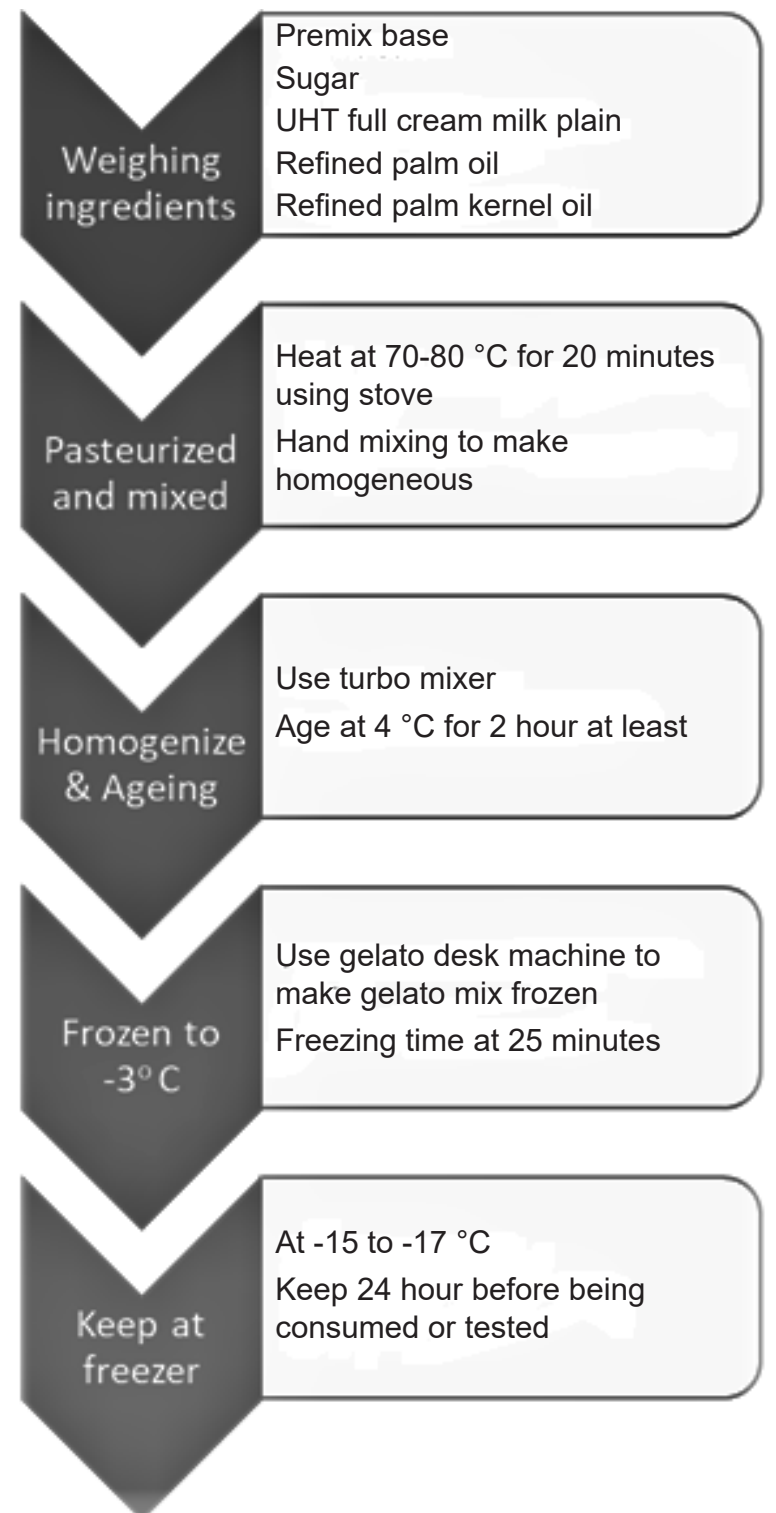

Figure 2 Gelato making process.

Table 3 Gelato Formulation with 30PO/70PKO fat blends

\begin{tabular}{lcrrrrr}
\hline Ingredients & UOM & \multicolumn{1}{c}{$0 \%$} & \multicolumn{1}{c}{$5 \%$} & $8 \%$ & $10 \%$ & $12 \%$ \\
\hline Panna base & $\%$ & 5.0 & 5.0 & 5.0 & 5.0 & 5.0 \\
Sugar & $\%$ & 10.0 & 10.0 & 10.0 & 1.0 & 10.0 \\
Refined PO & $\%$ & 0.0 & 1.5 & 2.4 & 3.0 & 3.6 \\
Refined PKO & $\%$ & 0.0 & 3.5 & 5.6 & 7.0 & 8.4 \\
UHT Milk & $\%$ & 85.0 & 80.0 & 77.0 & 75.0 & 73.0 \\
\hline Total & $\%$ & 100.0 & 100.0 & 100.0 & 100.0 & 100.0 \\
\hline
\end{tabular}

There were negative comments on taste fatty after taste with addition fat blends od $10 \%$ and $12 \%$. The scoop ability was assessed with scooping gelato form frozen
Table 4 Mouthfeel evaluation with 6 expert panelists at 7 point of scale, SD $=0.21, \mathrm{SL} 90 \%$

\begin{tabular}{lrrrrr}
\hline Attributes & $0 \%$ & $5 \%$ & $8 \%$ & $10 \%$ & $12 \%$ \\
\hline Overall like & 5.4 & 5.6 & 6.0 & 5.8 & 5.2 \\
Sweetness & 4.2 & 4.1 & 4.0 & 3.8 & 3.5 \\
Fatty after taste & 3.5 & 3.7 & 3.8 & 4.2 & 4.9 \\
Cold eating (icy) & 4.5 & 4.2 & 3.7 & 3.5 & 3.4 \\
Scoop ability & 4.5 & 4.7 & 5.1 & 4.9 & 4.9 \\
Easy to melt & 5.1 & 5.1 & 4.8 & 4.3 & 4.1 \\
\hline
\end{tabular}

gelato container to a cup. The more fat in formula made the product harder and more difficult to be scooped. The most preference was found at $8 \%$ fat blend. 


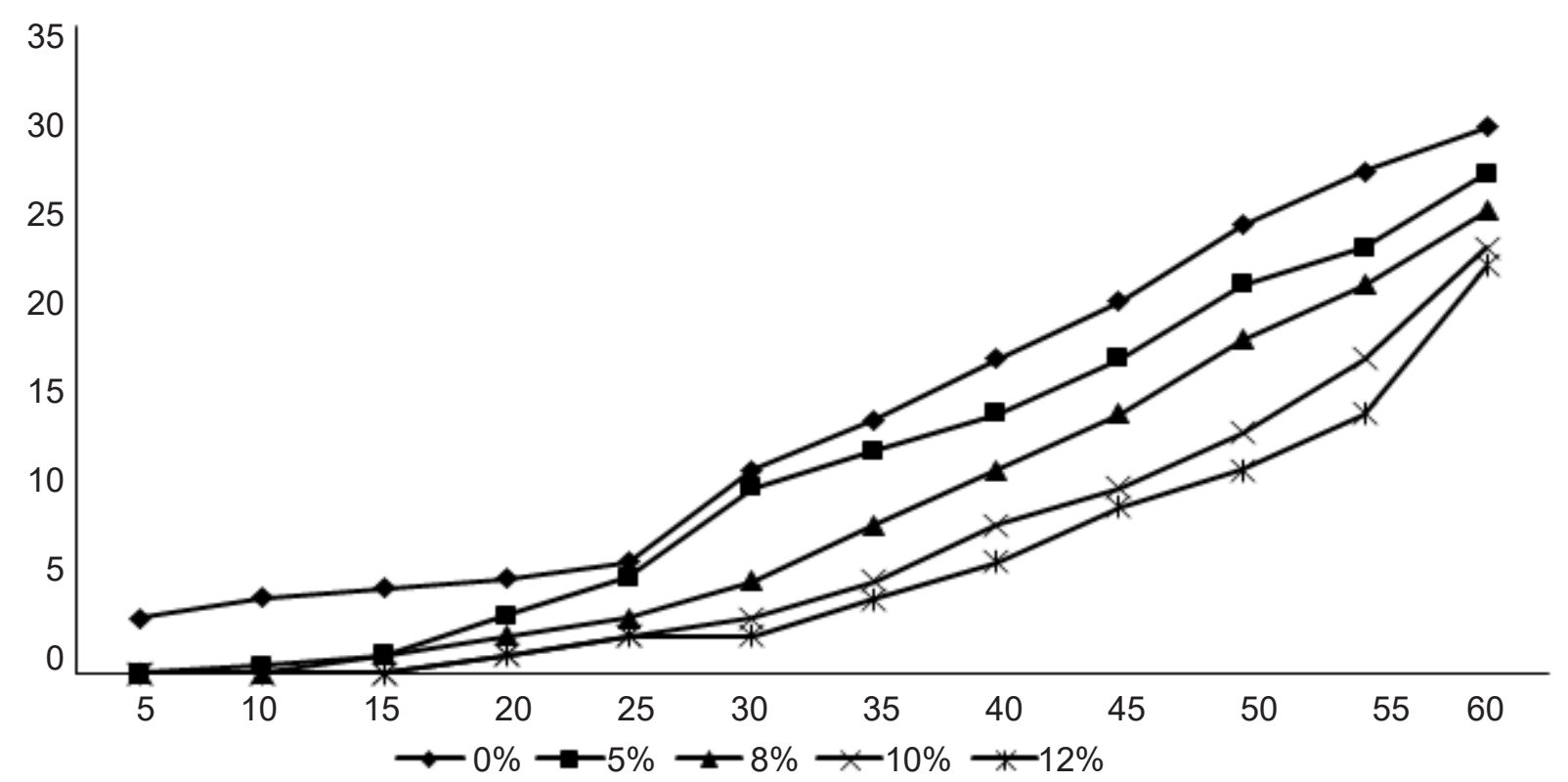

Figure 3 Dripped test at ambient $28{ }^{\circ} \mathrm{C}, \mathrm{SD} 0.23$.

Therefore, the addition of $8 \%$ 30PO/70P$\mathrm{KO}$ fat blend gave the optimum taste and scoop ability with this formulation.

\section{Economic Analyses}

The other consideration to use the $30 \mathrm{PO} / 70 \mathrm{PKO}$ fat blend is to see a possibility to replace cream milk with its butter oil inside. Having the economic analyses using formulation in Table 3, the addition of the fat blend made the cost of formulation getting cheaper. The Table 5 showed cost calculation with the reduced fresh milk with addition of fat blend as used in this research.

Therefore, the cost of gelato formulations was slightly cheaper to the formulations in this research. However, another economic analyses can be done as well as to the recommended formulation from Panna base. It used with fixed ratio on UHT full cream milk to the premix base. This cost analyses were for reference to get additional cost of fat blend to the gelato formulations. The percentage of formula was readjusted to the total mix. The fat blend was considered to add the cost of basic formulation to Panna Base (Table 6).
The additional cost from $1.72 \%$ to $4.13 \%$ at additional $5 \%$ to $12 \%$ fat blends were obtained from this financial calculation. Therefore, the additional cost for the $8 \%$ fat blend of $30 \mathrm{PO} / 70 \mathrm{PKO}$ was $2.75 \%$.

\section{CONCLUSION}

The addition of fat blend 30PO/70 PKO in the standard gelato formulation using Panna Base premix showed improvement on melting properties. The level of additional fat blend effected degree of less dripping to no added fat blend. Howev$\mathrm{er}$, the more fat blend in the formulations made the more mouthfeel fatty after taste. The good acceptance was at $8 \%$ fat blend with better scoop ability and melting behavior at ambient temperature.

The growth of gelato shops can be extended with mobile gelato for more impulse or out of home consumption of gelato. One of the great characters of gelato is its naturalness with fresh ingredient addition. Adding palm oil and palm kernel oil in gelato made enrichments of natural ingredients which made improvement on taste, melting, and cost as well. 
Table 5 Cost calculation based on varied UHT Full Cream

\begin{tabular}{lrrrrrr}
\hline Ingredients & $\begin{array}{r}\text { Price } \\
\left(\mathrm{Rp} . \mathrm{kg}^{-1}\right)\end{array}$ & $0 \%$ & $5 \%$ & $8 \%$ & $10 \%$ & $12 \%$ \\
\hline UHT full cream plain & 17000 & 14450 & 13855 & 13498 & 13260 & 13532 \\
Cane sugar powder & 12100 & 1210 & 1210 & 1210 & 1210 & 1210 \\
Panna base 50 & 350000 & 17500 & 17500 & 17500 & 17500 & 17500 \\
Fat blend (100PKO) & 12000 & 0 & 420 & 672 & 840 & 648 \\
$70 \%$ & 10000 & 0 & 150 & 240 & 300 & 360 \\
Fat blend (100PO) & & 33160 & 33135 & 33120 & 33110 & 33250 \\
$30 \%$ & & & -0.08 & -0.12 & -0.15 & -0.27 \\
Total mix cost & & & & & & \\
Less cost (\%) & & & & & & \\
\hline
\end{tabular}

Table 6 Cost calculation based on varied UHT Full Cream

\begin{tabular}{lrrrrrr}
\hline Ingredients & $\begin{array}{r}\text { Price } \\
\left(\mathrm{Rp.} \mathrm{kg}^{-1}\right)\end{array}$ & $0 \%$ & $5 \%$ & $8 \%$ & $10 \%$ & $12 \%$ \\
\hline UHT full cream plain & 17000 & 14450 & 14450 & 14450 & 14450 & 14450 \\
Cane sugar powder & 12100 & 1210 & 1210 & 1210 & 1210 & 1120 \\
Panna base 50 & 350000 & 17500 & 17500 & 17500 & 17500 & 17500 \\
Fat blend (100PKO) & 12000 & 0 & 420 & 672 & 840 & 1008 \\
$70 \%$ & 10000 & 0 & 150 & 240 & 300 & 360 \\
Fat blend (100PO) & & 33160 & 33230 & 14072 & 34300 & 34528 \\
$30 \%$ & & +1.72 & +2.75 & +3.44 & +4.13 \\
Total mix cost & & & & & & \\
Less cost (\%) & & & & & & \\
\hline
\end{tabular}

\section{ACKNOWLEDGEMENT}

Great appreciation to the kitchen team at Kemenady Co-creation Center in Sentul City Bogor. Their solid works made this research possible in very short time. Many thanks as well to Asian Agri R\&D team which gave samples and assistance during implementation of palm oil and palm kernel oil in this gelato formulations.

\section{REFERENCES}

[AOAC] Association of Official Analytical Chemists. 1995. Official methods of analysis of the association of official analytical chemists, 14th ed. Arlington (VG): AOAC, Inc.
[BPOM] Badan Pengawasan Obat dan Makanan. 2016. Peraturan Kepala Badan BPOM No. 21 tentang Kategori Pangan, Jakarta.

Devi A, Kathar BS. 2017. Thermo physical properties of fat and oils. IJETR. 7(2):45-50.

Dos SET, Gerbaud V, Roux Le GAC. 2014. Solid Fat Content of Vegetable Oils and Simulation of Interesterification Reaction: Prediction form Thermodynamic Approach. Toulouse (FR): OATAO.

Marshall TR, Arbuckle WS. 2000. Ice Cream. 5th Edition. Maryland (US): An Aspen Publication. 